\title{
Strategies the American Society for Engineering Education and Colleges of Engineering Can Use to Meet the Need for Engineering Graduates
}

\author{
Walter W. Buchanan ${ }^{1}$ \\ 1. Professor of Electronic Systems Engineering Technology, Dwight Look College of Engineering, \\ Texas A\&M University, College Station, Texas, 77843, buchananw@tamu.edu
}

\begin{abstract}
In our increasingly technological world the need for well-educated engineers continues to rise. In the United States the President's Council on Jobs and Competitiveness has declared a national goal of graduating 10,000 more engineers a year. Currently only a little more than seventy thousand engineering bachelor's degrees are awarded each year down from almost eighty thousand degrees awarded in 1985. The reasons for this are many including increasing tuition especially in public schools due to declining state funding, and recruitment and retention issues.
\end{abstract}

Keywords: engineering graduation rates, preparation for engineering studies, institutional transfer, distance education

\section{Strategies to Increase Graduation Rates}

Several universities are working to increase engineering graduation rates including the University of Florida, Iowa State University, and Michigan Technological University. These schools are working to increase their engineering graduation rates from fifteen to twenty percent over the next several years. [1] My own Texas A\&M University may be the most notable in this effort. Our vice chancellor and dean of engineering, M. Katherine Banks, has initiated plans to expand our engineering enrollment up to 25,000 students by 2025 . This ' 25 by 25 ' initiative was driven largely by the national need for more engineers including Texas. The Texas Workforce Commission has projected the need for engineers entering the workforce will increase significantly over the next 12 years. Texas A\&M received more than 10,000 applications for just 1,600 undergraduate spots at our college of engineering this past year. This combined with the fact that the high school graduation rate for Texas is significantly increasing means that the number of applications will continue to increase.

The ' 25 by 25 ' initiative has three guiding principles, which are to increase accessibility to engineering education at all levels; transform the educational experience to better prepare students to engage in and meet the future needs of the engineering marketplace; and to deliver engineering education in a cost-effective and affordable manner. The plan is to leverage existing resources to deliver a high-quality education by transforming engineering education to mold the engineer of the future. Curricula will be enhanced through technology-enabled learning, and an extensive professor of the practice program will be established for industry leaders to return to the classroom. To further help encourage growth, we are also partnering with local community colleges to help transition students into the university's engineering program. One of the pilot programs at our local Blinn Community College is to increase the current 500 pre-engineering students to 2,500 by 2025 . These students will then transfer into Texas A\&M to get an engineering bachelor's degree. We are also planning outreach programs with K-12 students in order to help encourage students to look and be prepared for an engineering curriculum as they move toward the university level.

As President of the American Society for Engineering Education (ASEE) this past year I have also worked to make ASEE a player in helping to solve this engineering graduation rate problem including getting students 
interested and excited about engineering careers early in their elementary and secondary school education, and making engineering education more affordable through encouraging more students to start their engineering education at two-year schools where tuition is typically less. Another strategy is to work to make distance education more accessible including hybrid courses that combine in class and distance education. [1]

\section{Preparation for Engineering Studies}

Our K-12 and Precollege Division is working to get students interested and excited about engineering careers early in their elementary and secondary school education. Its members are largely discipline engineers working in higher education who utilize their engineering skills in the K-12 classroom. Starting in kindergarten and continuing through high school, division members' work with teachers, students and parents to teach engineering as a process for problem solving, systems thinking and collaboration. Constraints, criteria and failure are used as ways to frame problems and solutions. While pre-engineering classes exist at the high school and middle school levels, most often engineering is taught as an integrator of other subjects. In other words, students use the math, science, language arts, social studies and arts topics they are taught to solve contextual problems using engineering design. This context and application is important-- research indicates students decide whether they like math and/or science in mid-elementary school. Therefore, this early involvement is essential for students to not only learn about engineering as a process, but also as a potential career because their familiarity with it positions them to make informed choices about their post-secondary lives. Efforts to expand engineering and technological literacy in the K-12 classroom are not only strategic but appealing, as investment supporting research and practice continues to significantly increase each year. Another effort, the Next Generation Science Standards currently under development provide a unique opportunity for engineering educators to impact student achievement and career choices. With the addition of attributes of engineering design into these standards, we have the potential to reach most students in this country. Our K-12 division colleagues have established ASEE as a center of competency for K-12 engineering research and practice, with members participating in virtually every level of science, engineering and STEM policy, research and practice efforts currently underway. Through their work, and the work of ASEE members in general, the awareness of engineering as a distinct field of study will increase. ASEE is uniquely positioned to significantly impact efforts to increase the general public's engineering and technological literacy necessary for success in the 21 st century. By exposing more students at earlier ages to what engineers and engineering technologists do to advance society, we are equipping them to enter a profession with tremendous potential to not only earn a good living but to change the world. Engineers in both industry and higher education must collaborate to create an environment ensuring that by the first year of high school, every American student should be aware of the opportunities and income potential in engineering and engineering related fields, know the educational qualifications for these positions, have the opportunity to interact, virtually and face to face, with engineers to learn about their jobs, educational experiences and the industry or university where they work, and be able to identify qualified universities that enable them to obtain the skills for these positions. This is an ambitious, but our students should have every question answered and be able to prepare for their careers while in high school. ASEE is in the ideal position to take steps that meet this goal. By investing our expertise in developing engineering awareness and habits of mind beginning at the start of a student's education career and continuing through high school graduation, we are strategically addressing the need to create more, and more diverse students, who will choose engineering and engineering related fields as their career choice. [2]

\section{Institutional Transfer}

To make engineering education more affordable through encouraging more students to start their engineering education at two-year schools where tuition is typically less, I have worked with ASEE to enhance the reputation of community colleges among high school students. College counselors in high schools should emphasize community colleges as a recognized and a respectable college option and provide students with information about transfer compatible schools and courses. For instance, when students are being informed about particular majors at certain colleges and universities, counselors should present them with the option of beginning that major at any of the community colleges that offer that major and have transfer agreements with the institution. They could also 
highlight the advantages of selecting the community college route, which include less tuition cost, more emphasis on teaching, more personalized education (smaller student faculty ratio), reduced need to work, and thus more focus on academics, which is imperative for the initial college years when students are trying to settle down. We can also work on creating a network of standardized transfer agreements between community colleges and four-year institutions for transferable courses that are acceptable across the nation. For instance, a chemical engineering curriculum could be created which would be offered at several community colleges across the nation and tenderable to different four-year institutions in several states. The agreements could be regulated by ASEE, ABET, or a related organization. Overall, however, the all too common difficulty of two-year to four-year transfer is getting proper student counseling. It is not unusual for a transfer student to lose at least a semester of student credit hours due to this problem. Better counseling and good articulation agreements can go a long way in alleviating this problem. In addition to teaching, transfer counseling should become one of the major responsibilities of faculty. Prior experience has shown that when faculty members themselves (as opposed to external counselors) are involved in student transfer advising and articulation, the transfer process becomes smoother, more efficient and seamless. Thus, funds and resources should be made available to train faculty and encourage them to participate enthusiastically in student transfer advising and articulation. I have worked to see ASEE is a player in this and worked with our 2-year ASEE faculty to find a solution. [3]

\section{Distance Education}

The last strategy I have worked on is to make distance education more accessible including hybrid courses that combine in class and distance education. In higher education these days the "next big thing" appears to be MOOCs (Massive Open Online Courses). A MOOC can be delivered by one instructor to thousands of students all over the world. The real question for MOOCs is if they can deliver effective education. This should involve competency-based education, whether the knowledge in obtained from an online course or through prior learning. Regents College, founded in 1971, and then part of the State University of New York (SUNY) system, became the first college in the nation to award degrees based on proof of prior learning. It became an independent non-profit in 2001 and renamed Excelsior College. At the center of the Excelsior College mission and strategic plan is the idea of "What you know is more important than where or how your learned it." Excelsior has been a pioneer of competency-based learning and designed a student centered model which is very responsive to the needs of careeroriented adult learners at a distance. The system integrates transfer credits from approved sources, courses from Excelsior and other institutions, and credits earned through assessment exams and prior learning evaluation. This competency-based model has expanded to other public colleges nationwide including Thomas Edison State College, founded in 1972 in New Jersey, and more recently and well known, the Western Governors University. Western Governors has expanded rapidly to over 25,000 students in just a few years. Another recent player in the online arena is the Colorado State University - Global Campus, which is the first and only $100 \%$ online, fully accredited public university in the United States. Now many other universities are starting to offer online courses and exploring ways to give credit for prior learning. Traditional universities such as Southern New Hampshire University is expected to soon be the first college that will award federal student aid based not on credit hours, but on a series of measured competencies. And many other universities are considering or starting to give credit for MOOCs, California State University, Arizona State, the University of Cincinnati, the University of Arkansas system, and Georgia State University, just to name a few. The real question in all of this is that if this learning is as good as from traditional instruction. Most of us would probably agree that with adequate finances going to a residential four-year school is the ideal situation due to the social atmosphere and face-to-face instruction with feedback. However, today's student is often not the 18 year old of times past. In fact, non-traditional students, that are adult learners returning to school, now outnumber the traditional students in college courses. This being said, adult students often cannot drop out of work to attend college courses during the day. Their choices are often limited to face-to-face courses in the evening or online courses. However, in today's economic environment college of any sort is becoming more and more unaffordable to a large number of students. Whether MOOCs are the answer, is yet to be determined. Whichever road we eventually take, we need to be sure that the education that is received is not watered down to fit the circumstances of life. Such an education would do a great disservice not only to the individual but to 
society in general. [4] So in summary, as ASEE president, I have worked on all three of these initiatives to help solve the problem of not enough engineering graduates to meet the needs of our increasingly technological society.

\section{References}

1. Grose, T. K., “The 10,000 Challenge,” ASEE Prism, 21 (6), February 2012, pp. 32-35, American Society for Engineering Education, Washington, D.C.

2. Buchanan, W. W. "Our Role Expands: Engineering Education Becomes a K-20 Systems Issue," ASEE Prism, 22 (1), September 2012, pp. 57-58, American Society for Engineering Education, Washington, D.C.

3. Buchanan, W. W., "The Transfer Option: ASEE Should Bolster Opportunities Offered by Community Colleges," ASEE Prism, 22 (6), February 2013, pp. 37-38, American Society for Engineering Education, Washington, D.C.

4. Buchanan, W. W., "To MOOC or Not - Online Courses Fit Well with Competency-based Education," ASEE Prism, 22 (9), Summer 2013, pp. 41-42, American Society for Engineering Education, Washington, D.C.

\section{Biography}

Walter W. Buchanan is Professor of Electronic Systems Engineering Technology at Texas A\&M University. He received his BSE and MSE from Purdue University, his Ph.D. and J.D. from Indiana University, and is a Professional Engineer in six states. Buchanan has served in various professorial and administrative positions at Indiana University-Purdue University Indianapolis, the University of Central Florida, Middle Tennessee State University, Oregon Institute of Technology, and Northeastern University. While in industry, he was an engineer for the Martin Company, the Boeing Company, the U.S. Navy, and the Naval Avionics Center. He is a past member of the Board of Directors of NSPE, Past Chair of the Engineering Technology Council of ASEE, and a past member of the Executive Committee of TAC of ABET. He has received NSF grants, is the author of over 200 papers on engineering technology education, is a Fellow of ASEE and NSPE, and is a Senior Member of IEEE and SME. He is currently the Immediate Past President of ASEE. 